\title{
SOSIALISASI PENCEGAHAN PENULARAN VIRUS COVID - 19 PADA KARANG TARUNA RW 06 KELURAHAN LIMO, DEPOK
}

\author{
Dewi Ningsih", Neneng Khoiriah $^{2}$, Sari Karmiyati ${ }^{3}$, Abdullah ${ }^{4}$, \\ Aan Purnama ${ }^{5}$ \\ Universitas Pamulang \\ Email: dosen02453@unpam.ac.id
}

\begin{abstract}
Community Service Activities carried out by a team of lecturers in the undergraduate management study program of Pamulang University in 2020 are community service activities that focus on socialization and counseling about Corona Virus or Covid - 19 to youth youths, youth organization $R W .06$, Limo. This activity began with a presentation about this virus and continued with the socialization of how this virus infects humans as well as discussions about this virus. 95\% of youths from Karang Taruna RW.06 Limo participated in our community service online using the zoom application. With this activity, it is hoped that it can be used as new knowledge for the youth and youth of Karang Taruna RW.06 Limo.
\end{abstract}

Keywords: Corona Virus, Science, Socialization.

\begin{abstract}
ABSTRAK
Kegiatan Pengabdian Kepada Masyarakat yang dilakukan oleh tim dosen program studi manajemen S1 Universitas Pamulang tahun 2020 merupakan kegiatan pengabdian kepada masyarakat yang menitikberatkan pada sosialisasi dan penyuluhan tentang Corona Virus atau Covid - 19 kepada para pemuda pemudi karang taruna RW.06, Limo. Kegiatan ini diawali dengan pemaparan tentang virus ini dan dilanjutkan dengan sosialisasi bagaimana virus ini menginfeksi manusia serta diskusi tentang virus ini. Diperoleh 95\% pemuda - pemudi Karang Taruna RW.06 Limo ini mengikuti pengabdian masyarakat yang kami lakukan melalui daring menggunakan aplikasi zoom. Dengan adanya kegiatan ini diharapkan dapat dijadikan pengetahuan baru bagi pemuda dan pemudi Karang Taruna RW.06 Limo.
\end{abstract}

Kata Kunci: Virus Corona, Ilmu Pengetahuan, Sosialisasi.

\section{A. PENDAHULUAN}

Coronavirus adalah keluarga besar virus yang menyebabkan penyakit mulai dari gejala ringan sampai berat. Ada setidaknya dua jenis coronavirus yang diketahui menyebabkan penyakit yang dapat menimbulkan gejala berat seperti Middle East Respiratory Syndrome (MERS) dan Severe Acute Respiratory Syndrome (SARS). Coronavirus Disease 2019 (COVID-19) adalah penyakit jenis baru yang belum pernah diidentifikasi sebelumnya pada manusia. Virus penyebab COVID-19 ini dinamakan SarsCoV-2. Virus corona adalah zoonosis (ditularkan antara hewan dan manusia). Penelitian menyebutkan bahwa SARS ditransmisikan dari kucing luwak (civet cats) ke manusia dan MERS dari unta ke manusia. Adapun, hewan yang menjadi sumber penularan COVID19 ini masih belum diketahui 
(Kemenkes, 2020). Tanda dan gejala umum infeksi COVID-19 antara lain gejala gangguan pernapasan akut seperti demam, batuk dan sesak napas. Masa inkubasi rata-rata 5-6 hari dengan masa inkubasi terpanjang 14 hari. Pada kasus COVID-19 yang berat dapat menyebabkan pneumonia, sindrom pernapasan akut, gagal ginjal, dan bahkan kematian. Tanda-tanda dan gejala klinis yang dilaporkan pada sebagian besar kasus adalah demam, dengan beberapa kasus mengalami kesulitan bernapas, dan hasil rontgen menunjukkan infiltrat pneumonia luas di kedua paru (Kemenkes, 2020).

Kasus virus corona di Indonesia sudah berlangsung selama enam bulan sejak diumumkan pertama kali oleh Presiden Joko Widodo (Jokowi) pada 2 Maret 2020 silam. Hingga saat ini, kasus penyebaran virus yang pertama kali disebut menyebar di Wuhan, China tersebut belum menunjukkan tanda-tanda akan berhenti. Bahkan beberapa hari terakhir, kasusnya semakin melonjak. Berdasarkan data covid19.go.id, total jumlah kasus virus corona di Indonesia mencapai 174.796 kasus hingga Senin (31/8/2020). Dari jumlah itu, 7.417 pasien tercatat meninggal dunia, dan 125.959 pasien dinyatakan sembuh. Kota Depok tercatat terbanyak sementara dengan 177 kasus positif Covid-19. Ada penambahan 13 kasus Corona. Selanjutnya, Kota Bandung dengan 144 kasus, Kabupaten Bogor (68), Kota Bekasi (63), Kota Bogor (60), Kabupaten Bekasi (57), Kota Cimahi (32), Kabupaten Bandung (31), Kabupaten Bandung Barat (25), Kota Sukabumi (23), Kabupaten Subang (14), Kabupaten Karawang (9), Kabupaten Purwakarta (8), Kabupaten Sukabumi (6), Kabupaten Kuningan (5), Kota Tasikmalaya (5), Kabupaten Sumedang (4), Kabupaten Cirebon (3) dan Kabupaten Garut (3), Kabupaten Ciamis (2), Kabupaten Indramayu (2), Kota Banjar (2), Kabupaten Cianjur (1), Kabupaten Majalengka (1), dan Kota Cirebon (1). Secara nasional, data pemerintah pusat mencatat jumlah pasien positif Corona per hari ini mencapai 7.775 kasus. Rinciannya, sebanyak 647 orang meninggal dunia dan sembuh 960 orang. Provinsi DKI Jakarta masih menjadi wilayah penyumbang terbanyak kasus positif Corona dengan 3.517 kasus. Sedangkan, Jawa Barat yang berbatasan wilayah dengan Jakarta berada di urutan kedua. Kasus virus Corona atau Covid-19 hampir merata ditemukan di seluruh kelurahan di Kota Depok. Berdasarkan data yang dirilis di Pusat Informasi Covid-19 Kota Depok per 9 Mei 2020, 59 dari 63 kelurahan di Kota Depok memiliki kasus positif corona. Artinya, ada 4 kelurahan di Kota Depok yang belum memiliki atau terbebas kasus positif corona. Yaitu Kelurahan Leuwinanggung, Kelurahan Pengasinan, Kelurahan Bojong Pondok Terong dan Kelurahan Gandul.

Melihat analisis situasi diatas maka Kelurahan Limo harus melakukan pengawasan ketat di setiap RT agar mampu memutuskan mata rantai penyebaran virus corona atau Covid19. Kelurahan Limo harus mampu memanfaatkan organisasi pemerintahan yang bagus ini untuk mencegah penularan. Pergerakan manusia di tingkat RT/RW bisa dibatasi jika ada kemauan setiap stakeholder. Sementara itu berdasarkan pengamatan gerakan dari bawah sebagai sebuah kesadaran masyarakat mencegah penularan Covid-19 terlihat pada kegiatan warga di banyak kompleks perumahan. Mereka melakukan penyemprotan disinfektan secara mandiri di lingkungannya. Sejumlah kompleks perumahan terutama di Jabodetabek, sebagai episentrum penyebaran Covid-19, memasang alat semprot di pintu gerbang perumahan. Setiap warga dan tamu yang datang wajib masuk dalam ruang atau pintu semprot. Sebagian lagi menggunakan alat semprot manual. Di sisi lain, info mengenai status orang dalam pemantauan (ODP) cepat tersampaikan ke gugus tugas kota maupun kabupaten dari RT dan RW. 
Selama ini Karang Taruna bisa memberikan kontribusinya dalam berbagai upaya mengelola dan menangani masalah sosial. Seperti bencana alam, bencana sosial, dan berbagai dinamika baik lokal maupun nasional. Karang Taruna sudah teruji dengan berbagai situasi dan tantangan. Jadi dalam menghadapi pandemi virus Corona, Karang Taruna bisa mengambil peran positif dan mengambil peran berarti. Pilar sosial dianggap mengenal daerah masing-masing adalah kunci utama dalam penanganan COVID 19. Di lain pihak, sebagian dari Karang Taruna tersebut merupakan pendamping untuk penerima manfaat. Karang Taruna bisa menyosialisasikan berbagai kebijakan pemerintah, baik di pusat maupun di daerah, terkait percepatan pemberantasan virus Corona masyarakat atau penerima manfaat yang mereka dampingi. Karang Taruna juga bisa menggugah kesadaran masyarakat agar, misalnya, taat pada anjuran pemerintah untuk tetap tinggal di rumah. Tentu saja, dalam melaksanakan himbuan pemerintah pihak karang taruna juga perlu kehati-hatian, dan memperhatikan keselamatan dan kesehatan diri dan lingkungan. Untuk sosialisasi langkahlangkah pencegahan penyebaran virus, jangan lupakan ketentuan yang sudah digariskan.

Dengan keberadaan karang taruna seperti disampaikan diatas maka pemuda dalam hal ini karang taruna Kelurahan Limo harus dapat dilibatkan dalam upaya penanganan COVID 19 dengan lingkungan yang paling kecil yaitu Kelurahan Limo RW 06. Tujuan dasar pada saat terbentuknya Karang Taruna RW 06 (kami beberapa Dosen Universitas Pamulang yang membantu pembentukan Karang Taruna RW 06, pada saat Pengabdian Kepada Masyarakat beberapa waktu lalu) agar Karang Taruna sebagai generasi muda dapat bermanfaat dan membantu semua Program Pemerintah untuk masyarakat sekitar. Berdasarkan latar belakang masalah tersebut maka tim Pengabdian Kepada Masyarakat melakukan penyuluhan dengan judul "Sosialisasi Pencegahan Penularan virus corona Di Lingkungan Rw 06 Kelurahan Limo, Kota Depok".

Berdasarkan latar belakang masalah tersebut maka tim Pengabdian Kepada Masyarakat melakukan penyuluhan secara daring dengan judul "Sosialisasi Pencegahan Penularan Virus Corona Pada Karang Taruna Rw 06 Kelurahan Limo, Kota Depok".

\section{B. METODE PELAKSANAAN KEGIATAN}

Mengadakan kegiatan sosialisasi tentang Corona Virus atau Covid -19 yang dilaksanakan melalui daring dengan menggunakkan aplikasi zoom. Dengan kesediaan waktu yang ada dan terbatas, maka penyampaian materi kami lakukan dengan maksimal dan sesuai rencana yang sudah kami susun sebelumnya. Metode yang digunakan adalah metode sosialisai dan setelahnya kami adakan diskusi bersama narasumber dan peserta yang ada. Setelah menyampaikan materi tentang Corona Virus atau Covid - 19 beserta cara penularan dan pencegahannya, kami adakan sesi diskusi sebagai bahan evaluasi tentang materi yang telah kami sampaikan, sehingga hasil dari progam pengabdian masyarakat ini dapat kami lihat sejauh mana keberhasilannya: 


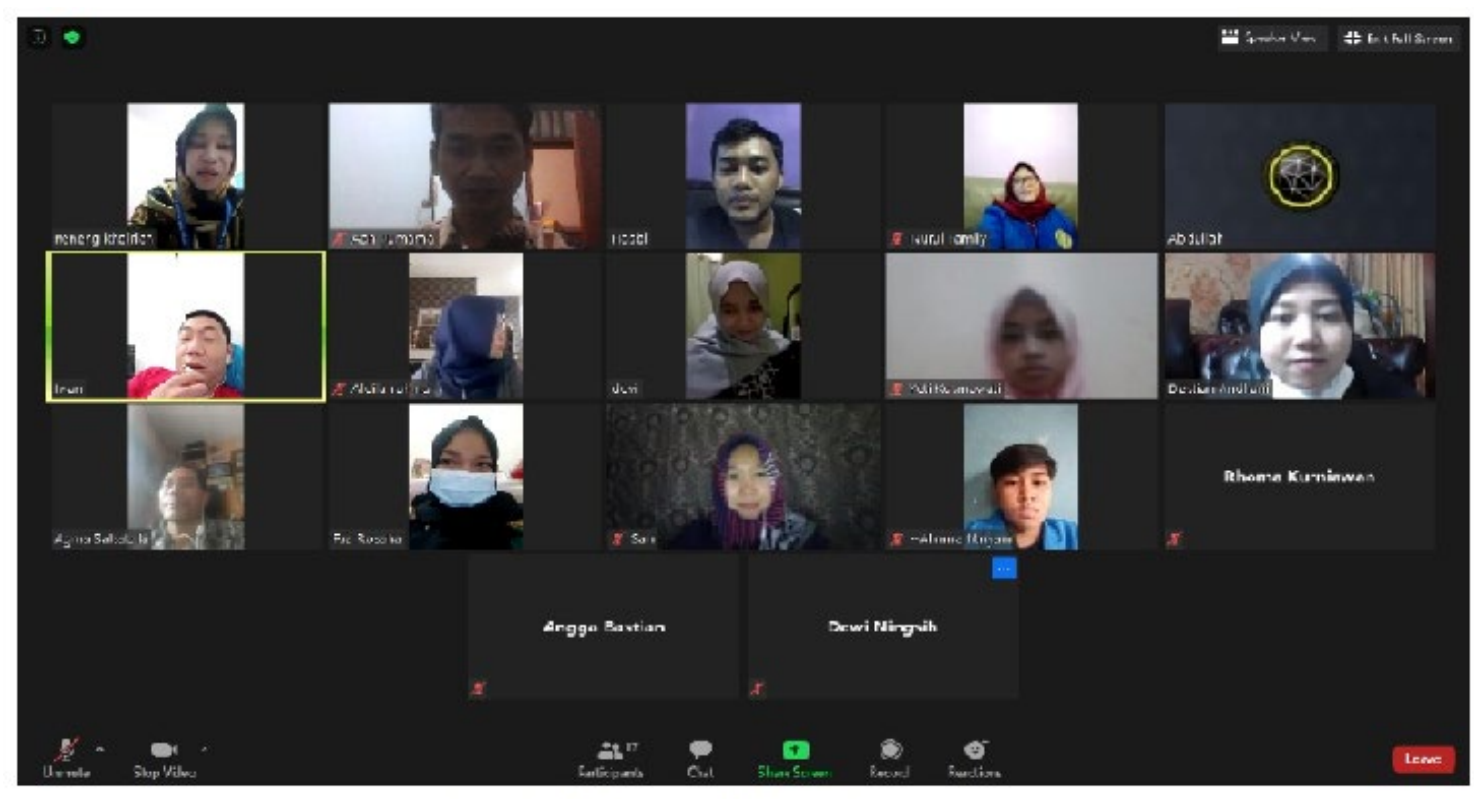

Gambar 1.1. Proses PKM via aplikasi zoom

\section{HASIL DAN PEMBAHASAN}

Covid 19 adalah penyakit menular yang diakibatkan infeksi virus coronavirus jenis baru. Penyakit ini diketahui muncul pertama kali di Wuhan, Cina pada Desember 2019 (WHO, 2020). Covid 19 merupakan penyakit pernafasan akut yang menjadi pandemik global dan disebabkan oleh novel coronavirus atau SARS-cov-2 (Erlich, 2020). Gejala covid 19 antara lain demam, batuk kering, dan sesak nafas. Beberapa pasien mengalami gejala mirip pilek dan mengalami nyeri pada tenggorokan dan diare. Beberapa orang yang terinfeksi tidak menunjukan gejala dan merasa sehat. Sebagian dapat pulih dengan sendirinya. Sedangkan sebagian lainnya mengalami pernurukan kondisi sehingga mengalami kesulitan bernafas dan perlu dirawat dirumah sakit (WHO, 2020).

Covid 19 dapat menular dari orang yang terinfeksi kepada orang lain sekitarnya melalui percikan batuk atau bersin. Covid 19 juga dapat menular melalui benda-benda yang terkontaminasi percikan batuk atau bersin penderita covid-19. Orang lain yang menyentuh benda-benda yang terkontaminasi tersebut lalu menyentuh mata, hidung dan mulut mereka maka dapat tertular penyakit ini (WHO, 2020). Virus penyebab covid-19 dapat bertahan di udara sekitar satu jam, sedangkan dipermukaan benda-benda dapat bertahan selama beberapa jam. Di permukaan berbahan plastik dan berisi tahan karat virus dapat bertahan hingga 72 jam, pada Cardboard selama 24 jam dan pada tembaga bertahan selama 4 jam (Van Doremalen, 2020).

Kegiatan pengabdian kepada masyarakat yang dilaksanakan adalah berjudul Sosialisasi Pencegahan Penularan Virus Corona Pada Karang Taruna Rw 06 Kelurahan Limo, Kota Depok. Hal ini diharapkan bermanfaat bagi warga RW.06 Limo, khususnya bagi pemuda dan pemudi Karang Taruna RW.06 Limo, Depok. Sedangkan harapan dari pelaksanaan pengabdian masyarakat ini adalah untuk menambah wawasan dan menambah kesadaran warga RW.06 Limo, Depok bahwa Covid - 19 ini merupakan virus yang cukup berbahaya terutama bagi seseorang yang memiliki penyakit bawaan, selain itu virus ini juga cukup cepat menular dari satu ke yang lainnya sehingga terjadi pandemi seperti saat ini. Hasil dari pemberian penyuluhan atau sosialisasi ini dapat memberikan tambahan bekal ilmu pengetahuan yang dapat dipertimbangkan untuk bermanfaat bagi masyarakat khususnya bagi 
para pemuda dan pemudi Karang Taruna RW.06 Limo, Depok. Dalam kegiaatan ini khususnya dalam diskusi tentang Covid-19, seluruh peserta pengabdian masyarakat sudah cukup memahami tentang corona virus ini.

\section{KESIMPULAN DAN SARAN}

\section{Simpulan}

Pelatihan yang dilakukan di wilayah Limo, tepatnya di Organisasi Kepemudaan Karang Taruna RW.06 sudah dilakukan dengan baik dan dapat diterima dengan peserta Pengabdian Kepada Masyarakat (PKM) dengan baik pula. Pelatihan dan pengembangan tentang SOSIALISASI PENCEGAHAN PENULARAN VIRUS COVID - 19 PADA KARANG TARUNA RW.06 KELURAHAN LIMO, DEPOK dapat dijadikan acuan dalam masalah penanganan pencegahan serta penularan Virus covid 19 yang sampai saat ini masih meresahkan masyarakat.

\section{Saran}

Dalam Pengabdian Kepada Masyarakat tentang SOSIALISASI PENCEGAHAN PENULARAN VIRUS COVID - 19 PADA KARANG TARUNA RW.06 KELURAHAN LIMO, DEPOK yang telah dilakukan diharapkan agar peserta mampu menerapkan serta mempraktekan dalam kegiatan sehari - hari.

\section{DAFTAR PUSTAKA}

Guan W, Ni Z, Hu Y, Liang W, Ou C et al. Clinical Characteristics of Coronavirus Disease 2019 in China. New England Journal of Medicine 2020 February 28. doi: 10.1056/NEJMoa2002032

Handayani, Annisa Yulia. (2015). Persepsi Pemuda terhadap Peranan Karang Taruna dalam Penanganan Masalah Sosial. Jurnal penyuluhan Vol.11 No.1

Kemenkes RI. (2020). Pedoman Pencegahan dan Pengendalian Coronavirus Disease (COVID-19). Germas, 0-115.

Peraturan menteri sosial Republik Indonesia NO: 77/HUK/2010. 2010. Pedoman Dasar Karang Taruna. Jakarta: Kemensos RI

Permensos 83/HUK/2005 tentang Pedoman Dasar Karang Taruna UU Nomor 40 Th 2009 tentang Kepemudaan Permensos 77 Th 2005 tentang Pedoman Dasar Karang Tarun

Suharta, R.B, (2009). "Pengembangan Organisasi Kepemudaan". Jurusan Pendidikan Luar Sekolah, Fakultas Ilmu Pendidikan Universitas Negeri Yogyakarta.Yogyakarta.

World Health Organization (2020). Responding to community spread of COVID-19 [online]. Website https://www.who.int/ publications-detail/responding-to-community-spreadofcovid-19 [accessed 12 April 2020].

World Health Organization (WHO) (2020). Advice on the use of masks in the context of COVID-19: interim guidance, 6 April 2020 [online]. Website https://apps.who.int/iris/ handle/10665/331693 [accessed 12 April 2020].

www.aladokter.com

www.wikipedia.com 